\title{
A Review of Studies on Cognitive and Metacognitive Reading Strategies in Teaching Reading Comprehension for ESL/EFL Learners
}

\author{
Aziza M. Ali ${ }^{1} \&$ Abu Bakar Razali ${ }^{1}$ \\ ${ }^{1}$ Faculty of Educational Studies, Universiti Putra Malaysia (UPM), Malaysia \\ Correspondence: Abu Bakar Razali, Department of Language and Humanities Education, Faculty of Educational \\ Studies, Universiti Putra Malaysia (UPM), 43400 UPM Serdang, Selangor, Malaysia.
}

Received: April 12, 2019 Accepted: May 11, 2019 Online Published: May 13, 2019

doi: 10.5539/elt.v12n6p94 URL: https://doi.org/10.5539/elt.v12n6p94

\begin{abstract}
Being able to read well is important for English language learners. Through the process of reading, the learner becomes an active participant in producing an interaction with the writer of the text through predicting, analyzing, summarizing and using other types of reading strategies. However, building such a connection between the reader and the written information of the text is complex and for English as a second language (ESL) and English as a foreign language (EFL) students, it can be quite difficult for them to apply different types of reading strategies. This article provides a review of literature on 27 studies on the teaching of reading strategies (particularly cognitive and metacognitive reading strategies) for ESL/EFL learners, which reveals that ESL/EFL teachers need to keep updating their teaching methods to meet the ESL/EFL students' needs, particularly in the use of correct reading strategies. The authors also highlight some of the main issues that prevent ESL/EFL students from improving and developing their reading comprehension. Furthermore, the authors discuss and conclude the article by suggesting to ESL/EFL teachers some teaching strategies to be applied in the reading lesson to improve the ESL/EFL students' use of reading strategies.
\end{abstract}

Keywords: reading comprehension, cognitive reading strategies, metacognitive reading strategies, English as a second language (ESL), English as a Foreign Language (EFL)

\section{Introduction}

Reading is a challenging process as it requires the involvement of various types of reading strategies, which includes Cognitive Reading Strategies (e.g., planning and goal setting, tapping prior knowledge, asking questions and making predictions, constructing gist, monitoring, revising meaning, reflecting and relating, and revising meaning) and Metacognitive Reading Strategies (e.g., problem solving reading strategy, global reading strategy, support reading strategy) which can be used to assist in understanding the reading text. Although there is a growing number of research focusing on the difficulties and the challenges faced by the students, reading still seems a struggle to most of English as a second language (ESL) and English as a foreign language (EFL) students; and one of the reasons could be related to the reading instruction in the classroom, particularly in teaching reading strategies to these students. Some researchers also believe that students may know the reading strategies but they might need continuous practice to better understand these strategies (i.e., Nasab \& Ghafournia, $2016 \&$ Wai et al., 2014). Apart from the reasons mentioned above, the authors of this article also believe that another reason could possibly be that English language teachers might prefer using only certain reading strategies instead of using diverse reading strategies to make sure the students read better.

Teaching and practicing many different types of reading strategies can be time-consuming and challenging sometimes for students. Therefore, it is advised for the language teachers to try teaching different types of reading strategies that are suitable to the students' needs, which are according to their level of English proficiency, and suitable with the genres of texts - especially if and when students have difficulties in understanding the texts especially if they use inappropriate strategies in doing so. Nasab and Ghafournia (2016) suggest that, "before implementing such a framework in our classrooms, we should determine the relevance and effectiveness of these strategies. This is also possible by a teacher to informally try each strategy and find out about the feedback in terms of students' reaction and their effects in class achievement." (p. 39). In this regard, the 
authors also share this position because it is important to teach reading strategies according to the students' level of English proficiency as well as their learning needs. As such, the authors are intrigued as to how English language teachers actually teach their ESL/EFL students using these reading strategies to make them better readers. The authors carefully selected and reviewed 27 research articles to discover the types of reading strategies that have been used by English language teachers in teaching their ESL/EFL students.

This review of literature is divided into several major sections. The Reviewing the Literature section discusses the method used in selecting, gathering, and reviewing the carefully selected research articles that were reviewed in this article. The Reading Strategies Used in Teaching ESL/EFL Students section reports on the review of 27 carefully selected research articles on the use of cognitive and metacognitive strategies in the teaching and learning of ESL/EFL students reading comprehension. The authors also discuss the methodologies used in studying the use of reading strategies in the teaching and learning of English reading comprehension among ESL/EFL English teachers and learners. In the Discussion and Conclusion section, the authors then discuss and conclude the article by reporting the summary of the reviews of these articles, and also by giving suggestions on the pedagogical implications with regards to the use of reading strategies in teaching and learning English reading, as well as research implications on further future investigations on the use of reading strategies in teaching and learning English reading.

\section{Reviewing the Literature}

The article presents a review of 27 research studies which focus on teaching reading strategies (particularly cognitive and metacognitive reading strategies) for ESL/EFL students. The studies were obtained through several online educational databases, such as Education Resources Information Center (ERIC), Science Direct and ResearchGate, as well as Google Scholar. The most highly used online database was Education Resources Information Center (ERIC) as 15 studies were obtained via this particular online educational database (i.e., Bastug \& Demirtas, 2016; K. Chen \& S. Chen, 2015; De Leon \& Tarrayo, 2014; Gomaa, 2015; Guo, 2013; Kasemsap \& Lee, 2015; Melekoglu \& Wilkerson 2013; Migdadi \& Baniabdelrahman,2016; Nurie, 2017; Omar \& Saufi, 2015; Semtin \& Maniam, 2015; Solak \& Altay, 2014; Teba, 2017; Ulu, 2017; Wai et al., 2014). Nine studies were obtained from Google Scholar (i.e., Alsheikh \& Mokhtari, 2011; Ciullo et al., 2016; Fu et al., 2014; Küçükoğlu, 2012; Lai, 2017; Lee \& Chang, 2017; Li, 2010; Nasab \& Ghafournia, 2016; Tercanlioglu, 2004). Two research studies were obtained from ResearchGate (i.e., AD- Heisat et al., 2009; Pinninti, 2016). One study was obtained from Science Direct (i.e., Yukselir, 2014).

The research articles found in these online databases were generated by using relevant keywords, such as "reading comprehension", "teaching reading strategies", and "improving reading through the use of reading strategies," "cognitive reading strategies," "metacognitive reading strategies," and so on. For the purpose of this article, the authors aimed to focus only on reviewing research articles that were related to the teaching and learning of reading strategies in the ESL/EFL classrooms (particularly on cognitive and metacognitive reading strategies). All of the 27 reviewed articles were published between the years 2009 to 2017. The reviewed articles were collected from countries whose participants are native and non-native speakers of the English language. Two reviewed studies were conducted in the United States of America and the other 25 reviewed studies were conducted in various countries, such as Malaysia, Turkey, Taiwan, Iran, Egypt, Jordan, United Arab Emirate, Philippine, Republic of Benin, Ethiopia, Hong Kong, China and India. The medium of instruction in all the reviewed studies was English language.

These articles were collected from various academic research journals, such as International Electronic Journal of Elementary Education, An International Online Journal, International Journal of Contemporary Educational Research, Learning Disability Quarterly, I-manager's Journal on English Language Teaching, International Journal of Education and Literacy Studies, International Journal of Psycho-Educational Sciences, EURASIA Journal of Mathematics Science and Technology Education, International Journal of Instruction, Journal of Education and e-Leaning Research, PASAA Journal of Language Teaching and Learning in Thailand, International Journal of Evaluation and Research in Education (IJERE), Journal of Education and Training Studies, International Journal of Special Education, International Educational Journal, The English Teacher Journal, Asian Social Science Journal, Journal of ELT and Applied Linguistic (JELTAL), Journal of Social and Behavioral Sciences (Procedia), International Online Journal of Education and Teaching, and Journal of Scientific Information Database (SID).

In reviewing these articles, the authors found that the most frequently used research design is the quantitative design as there were ten research articles reviewed that were quantitative in nature. Studies that were qualitative in nature were only eight, and two studies were conducted using a mixed method design. Unfortunately, the other 
seven research articles did not specify the research design. As for the research approach, the most frequently occurred research approaches used were the survey questionnaires followed by interviews, observation, analysis and descriptive approaches respectively. (See Appendix A - Literature Review Matrix). In terms of the number of participants in the research articles reviewed, the most focused population was on high school ESL/EFL students (see K. Chen \& S. Chen, 2015; Ciullo et al., 2016; De Leon \& Tarrayo, 2014; Nasab \& Ghafournia, 2016; Melekoglu \& Wilkerson, 2013; Migdadi \& Baniabdelrahman, 2016; Semtin \& Maniam, 2015; Teba, 2017; Pinninti, 2016). There weree six research conducted on elementary school ESL/EFL students (see Bastug \& Demirtas, 2016; Fu et al., 2014; Lee \& Chang, 2017; Gomaa, 2015; Melekoglu \& Wilkerson, 2013; Ulu, 2017) and only two studies that focused on primary school ESL/EFL students (see Guo, 2013; Omar \& Saufi, 2015). Seven reviewed studies focused on university students and language teachers (see Wai et al., 2014; Yukselir, 2014; Tercanlioglu, 2004; Nurie, 2017; Teba, 2017; AD- Heisat et al., 2009; Solak \& Altay, 2014). (See Appendix A Literature Review Matrix).

\section{Reading Strategies Used in Teaching ESL/EFL Students}

This section reports on the reading strategies from the 27 research studies in teaching reading comprehension strategies for ESL/EFL students. The section also discusses the research methods used by the researchers in these studies, which particularly includes detailed information on the participants and their age levels. This section is divided into two sub-sections according to the reading strategies, namely: 1) Cognitive reading strategies used in teaching ESL/EFL students and 2) Metacognitive reading strategies used in teaching ESL/EFL students.

\subsection{Cognitive Reading Strategies Used in Teaching ESL/EFL Students}

Before presenting the review of the studies on the use of Cognitive Reading Strategies in teaching ESL/EFL learners in reading comprehension, it is important to note that these strategies are often described and used in different terms, albeit they do share the most salient features of the Cognitive Reading Strategies espoused by many reading experts. In this sub-section, the authors will first present the definitions and terms used by experts in reading comprehension on the general ideas of Cognitive Reading Strategies. In doing so, the authors also report on the use of different terms and phrases used by researchers in the reviewed articles (to report their studies). Finally, in this sub-section, the authors report on their reviews of these research articles on the use of Cognitive Reading Strategies in teaching ESL/EFL reading comprehension.

In its core definition, Semtin and Maniam (2015) associate Cognitive Reading Strategies with "specific learning tasks and employed in the learning process, such as relating the new words in mind and writing down the main idea" (p. 55). These strategies assist and guide the students to understand the reading content through rereading the text, scanning, analyzing and summarising, and they also include the use of the first language to produce ideas. Cognitive Strategies are connected with Comprehending Strategies (i.e., dictionary, translating), Memory Strategies (i.e., underlining and highlighting information, visualizing read information) and Retrieval Strategies (i.e., previewing text before reading, using prior knowledge, using context clue to ascertain the meaning). They are used to encourage the students to read slowly to analyze and visualize the reading text. According to Semtin and Maniam (2015), Cognitive Strategies are also identified as Reciprocal Teaching Intervention Strategy (i.e., questioning, summarizing, clarifying, and predicting), Planning Strategies (i.e., pausing and thinking about reading, trying to stay focused on reading, scanning the text, reading slowly and carefully and determining what to read) and Monitoring Strategies (i.e., rereading the text, paying attention to reading, and asking oneself questions). They control the learning process through setting a purpose for reading, predicting, assessing self-understanding and directing attention.

Within the 27 collected research studies, there are 17 studies that focused on Cognitive Reading Strategies. From the reviewed past studies on Cognitive Reading Strategies, many researchers reported frequent use of comprehending strategies as they are viewed to be highly used among ESL/EFL students, especially the use of the translation strategy followed by the use of the retrieving strategy and memory strategy (see Guo, 2013; Teba, 2017; Semtin \& Maniam, 2015; Yukselir, 2014; AD- Heisat et al., 2009; Küçükoğlu, 2012; Kasemsap \& Lee, 2015; Alsheikh \& Mokhtari, 2011; Tercanlioglu, 2004; Solak \& Altay, 2014; Pinninti, 2016; Lai, 2017). These researchers also reported that students with low proficiency level used the memory strategy more often than students with a high level of proficiency. Semtin and Maniam (2015) also reported a low frequency of occurrence in the use of skimming strategy among students with low proficiency level.

A number of researchers found a high frequency use of reciprocal teaching intervention strategy 'questioning, summarizing, clarifying, and predicting', planning strategies 'pausing and thinking about reading, trying to stay focused on reading, scanning the text, reading slowly and carefully, determining what to read and monitoring strategies, such as rereading the text, paying attention, treading, and asking oneself questions (see Semtin \& 
Maniam, 2015; Kasemsap \& Lee, 2015; Alsheikh \& Mokhtari, 2011; Küçükoğlu, 2012; Tercanlioglu, 2004; Pinninti, 2016; Ulu, 2017; Gomaa, 2015; Heisat et al., 2009; Kasemsap \& Lee, 2015). However, the use of summarization strategy was reported to have a low frequency of occurrence, although it highly occurred in one article (see Semtin \& Maniam, 2015).

From the review of the collected research articles, it was found that some researchers also used different types of Cognitive Reading Strategies using the mediums of technology to explore the effectiveness of using the strategies in reading comprehension. For example, Fu and colleagues (2014) examined the effectiveness of using online storybooks and found that the most commonly used types of reading strategies when discussing and reading online storybooks are predicting, inferencing, and identifying, whereas, the least commonly used reading strategy is monitoring comprehension. However, there are also instances where the use of technology-based and network-based tools to promote cognitive reading strategies appear to have mixed findings in helping ESL/EFL students with reading comprehension. For example, Wai and colleagues (2014) examined the effectiveness of using technology-based phonological and orthographic strategies (i.e., the rule-based strategy, the visual imagery strategy) to teach spelling and other skills on students with dyslexia. The technology that they used alongside the teaching of this particular phonology strategy is the use of interactive elements (i.e., interesting songs, colourful flashcards and presentations) to keep the students motivated and interested in learning. The findings from this study indicated that by using the orthographic strategy, the visual imagery was the least effective strategy to be used as it only helps with short-term memory. As for the phonological strategy, it does not seem to assist the students in highlighting the silent letters in the words and the rule-based strategy does not help in identifying the spelling problems faced by the students. However, among the examined strategies, the phonological and rule-based strategies are believed to be effective, although, they are still not proven to be the best structured strategies to be applied to students with dyslexia. In this regard, the researchers believe that to find the most effective strategies to be used, the teachers need to set the learning focus for each lesson and adjust their teaching strategies to meet the needs of the students. The researchers concluded by suggesting that "to find the most effective strategy in teaching children with dyslexia spelling, learning style and preferences, language proficiency and learning habits should all be taken into account so as to conduct the most suitable and most effective strategy to teach" (p. 22).

\subsection{Metacognitive Reading Strategies Used in Teaching ESL/EFL Students}

Similar to the previous sub-section, before presenting the review of the studies that focus on the use of Metacognitive Reading Strategies in teaching ESL/EFL learners in teaching reading comprehension, the authors will first present the definitions and terms used by experts in reading comprehension on the general ideas of Metacognitive Reading Strategies. The authors later report on the use of different terms and phrases used by researchers in the reviewed articles (to report their studies). Finally, in this sub-section, the authors report on their review of these research articles on the use of Metacognitive Reading Strategies in teaching ESL/EFL learners teaching reading comprehension.

Semtin and Maniam (2015) describe the Metacognitive Strategy as a technique that requires "planning for learning, thinking about the learning process that takes place, monitoring of one's comprehension, and evaluating learning after completion of a task" (p. 55). Metacognitive Reading Strategies are concerned with mainly three strategies, namely, 1) Problem-Solving, 2) Global Reading, and 3) Support Reading. These Metacognitive Strategies assist the language teachers to better understand their students' different reading styles and identify the most impactful reading strategies to be taught in the language classroom. Semtin and Maniam (2015) also indicated that Problem-Solving Strategy focuses on assessing the students to solve reading problems when they are reading difficult texts which include adjusting the reading speed, rereading the text, reading aloud, and guessing the meaning of the difficult words. Global Reading Strategy, on the other hand, focuses on guiding the students to have a reading purpose in mind when reading a text which can be increasing vocabularies and getting more information on specific topics. As for Support Reading Strategy, it focuses on providing the students with extra reading techniques, which include using some reference materials, such as the dictionary, taking notes and underlining particular sentences to remember, asking self-questions to find the answers, and paraphrasing the paragraphs.

The authors managed to also find a few reading strategies used in the 27 research studies, which were regarded as "reading aloud," "evidence-based literacy practices," and "motivational strategies," all of which (after further reading and analysis) was found to fall under the Metacognitive notion of reading strategies. "Reading aloud" (which is based on the ideas of Problem-Solving and Support Metacognitive Reading Strategies) is viewed as an effective strategy because it builds a direct interaction between the teacher and the students. Reading aloud also is believed could motivate and interest the students to read and share their thoughts with everyone in the 
classroom (Migdadi \& Baniabdelrahman, 2016). Through students reading aloud, the teacher can give immediate feedback as the teacher can focus on pronunciation and fluency in reading. Moreover, Omar and Safi (2015) view the reading aloud strategy as the most effective strategy because it also involves the students in "asking and answering questions, giving comments and making predictions through guidance of the teacher" (p. 109). As such, this technique is recommended to be used with all the language students, and in doing so the teachers need to select the reading text based on the learners' background knowledge and level. The students need to read texts and apply Metacognitive and Cognitive Strategies and connect them with real-life situations.

When reviewing these research articles, it is important to note that there is also the notion of "evidence-based literacy practices" (i.e., writing and reading observational tools (WROT)) which are reading and writing strategies related to developing a better-understanding in reading a text. Ciullo and colleagues (2014) found that this strategy focuses on writing a text in the classroom which would motivate and encourage the students to read more to become better in discussing and voicing their thoughts. As such, after further reading and analysis this strategy was found to fall under the Metacognitive Reading Strategy, to which it is based on the ideas of Problem-Solving and Support Reading Strategies. There is also "motivational strategy," to which Nasab and Ghafournia (2016) describe "motivational strategies" in the learning of reading process which include: talking about the students' needs and enthusiasm for the subject material or the reading text; making the learning process enjoyable to keep them interested in reading; and increasing their level of self-esteem. Due to the nature of this strategy, it can be concluded that this strategy also falls under Metacognitive Reading Strategy, under the notion of Support Reading Strategy. Furthermore, Melekoglu and Wilkerson (2013) believe that teachers need to devote appropriate time and attention to use motivational reading strategies in the classroom to improve the students' reading comprehension. They suggest that "teachers should blend and utilize various methods to increase the reading motivation" (p. 87).

There are also studies that reported on the use of Metacognitive Reading Strategies (i.e., particularly through the notion of Support Reading Strategy) through the use of technological gadgets and tools to motivate the students and increase their level of confidence when reading a text. There are various kinds of technology which have been used to strengthen the students' reading comprehension, espousing the notion of Support Reading Strategy, which includes e-books and online reading lessons. The ways to which these tools are used to aid reading is by using a set of e-books from a particular website named as 'e-yep' which has numerous English songs and stories to be used in the reading classroom. Fu and colleagues (2014) reported that the students were encouraged to read the title and look at the picture to predict the story and they were also taught on how to use the technical features on the online page to read the passage and enlarge the size of the picture of the reading passage. They even were encouraged to infer the meaning of the difficult words and predict the upcoming events of the story. The use of the online e-books motivated the students and they paid more attention in the classroom.

In this regard, there is also a number of studies that focused on the use of other technological gadgets, such as social networking which also espouses the notion of Support Strategy that encourages the students to read and think critically to improve their reading comprehension level. Lee and Chang (2017) adopted a particular reading comprehension screening test which was revised by Ko and Chan (2009). The reading activity was performed on Edmodo to encourage peer review interaction between the students on the website. They indicated that "networked peer support should be adopted to enhance the reading comprehension skills of students with an executive thinking style" (p. 1512). As such, scholars studying this particular field believe that the students need to get exposed to various kinds of reading technologies and tools and maintain regular use of technologies to increase their level of reading comprehension, particularly through the notion of Support Reading Strategy.

In the review of the 27 collected research articles, it was found that there are 22 studies that focused on Metacognitive Reading Strategies. In these reviewed studies, the most popular type of Metacognitive Reading Strategy reported is the Support Reading Strategy. Researchers from these reviewed studies found that among the most commonly used types of support reading strategies are: 1) the use of dictionary and their mother tongue, 2) the use of reading images, 3) reading aloud technique, and 4) note-taking (see Ad- Heisat et al., 2009; Kasemsap \& Lee, 2015; Li, 2010; Lia, 2017; Pinninti, 2016; Tercanlioglu, 2004; Bastug \& Demirtas, 2016). Based on these research findings, it is found that through the use of these Support Reading Strategies, the ESL/EFL students managed to improve their reading comprehension and increased their level of confidence, although they still encounter some difficulties from time to time.

On the other hand, there are quite a number of studies which focused on the use of Problem-Solving Strategy, such as rereading strategy and adjusting reading speed (see De Leon \& Tarrayo, 2014; Alsheikh \& Mokhtari, 2011; Ulu, 2017; Solak \& Altay, 2014). From these studies, it is found that rereading the reading passages and adjusting their reading speed helped them in understanding the contents of the text read. Meanwhile, in regards 
to the use of Global Reading Strategy, K. Chen and S. Chen (2015) found a high frequency of occurrence in the use of Global Reading Strategy, namely planning how to read and managing comprehension followed with Problem-Solving Strategy and Support Reading Strategy. The findings from their study show that female students had a slightly higher mean (i.e., Mean $=3.83$ ) in their use of the Global Reading Strategies, namely planning how to read and managing comprehension as opposed to the male students (mean $=3.68$ ).

The strategy of reading aloud (which is based on the ideas of Problem-Solving and Support Metacognitive Reading Strategies), was used by Omar and Saufi (2015) and they found great improvement in the students' reading fluency. It is suggested to choose purposeful stories that are connected and related to real-life situations to keep the students interested and engaged in the overall reading process. Nasab and Ghafournia (2016) found that the use of motivational strategies improved the students' level of reading confidence and they enjoyed the overall reading process. However, the findings of this study do not seem to correlate with the findings of another study conducted by Melekoglu and Wilkerson (2013) which found that the motivational level of the students with disabilities did not increase and the reason could be related to their physical and mental struggles, and therefore, they suggested that "reading teachers should consider focusing on the importance of reading for students' lives in addition to improving their reading skills" (p. 85).

From the review of the collected research article, it was found that these researchers used different types of Metacognitive Reading Strategies using the medium of technology to explore the effectiveness of using them in reading comprehension. For example, Lee and Chang (2017) explored the effectiveness of using network peer support strategy (which is based on the ideas of support metacognitive reading strategy) on high reading proficiency and low reading proficiency ESL/EFL students. The result showed that the students' level of reading proficiency improved as they managed to cooperate with their groupmates as well as their teachers online by using Edmodo educational networking site instead of doing the reading individually in the conventional way. This happened because the researchers indicated that the ESL/EFL students started "adopting the networked peer support strategy and promoting sharing and discussion among the students" (p. 1514). In addition, Ciullo and colleagues (2016) also highlighted significant findings related to the use of electronic teaching tools, such as iPads in the classroom with peer reading technique as it improved the students' language skills and enhanced on the effectiveness on peer learning and their comprehension of the text.

\section{Research Methodologies Used Research on Reading Strategies}

Throughout the reviewed studies, the authors found that most of the reviewed papers have different research focuses, such as identifying the effectiveness of using certain reading strategies on the students, highlighting the most and the least occurred number of strategies, highlighting and overcoming the challenges faced by the students, and examining specific teaching methods on reading strategies. Throughout the reviewed studies, the most highly studied reading strategies are cognitive reading strategies (see Guo, 2013; Semtin \& Maniam, 2015; Yukselir, 2014; AD-Heisat et al, 2009; Küçükoğlu, 2013; Kasemsap \& Lee, 2015; Alsheikh \& Mokhtari, 2011; Tercanlioglu, 2004; Solak \& Altay, 2014; Pinninti, 2016; Lai, 2017;Li, 2010; Gomaa, 2015) and metacognitive reading strategies (see AD- Heisat et al., 2009; Kasemsap \& Lee, 2015; Li, 2010; Lai, 2017; Pinninti, 2016; Tercanlioglu, 2004; and Bastug \& Demirtas, 2016; De Leon \& Tarrayo, 2014; Alsheikh \& Mokhtari, 2011; Solak \& Altay, 2014; K. Chen \& S. Chen, 2015).

With specific attention towards the used research designs in the reviewed studies, the authors found that the most frequently used research design is quantitative design as there are 14 research articles chose to analyse their data using the quantitative methodological approach (see see AD-Heisat et al., 2009; Alsheikh \& Mokhtari, 2011; Chen \& Chen, 2015; De Leon \& Tarrayo, 2014; Kasemsap \& Lee, 2015; Lai, 2017; Melekoglu \& Wilkerson 2013; Semtin \& Maniam, 2015; Yukselir, 2014; Wai, et al., 2014; Teba, 2017; Semtin \& Maniam, 2015; Migdadi \& Baniabdelrahman,2016; and Nasab \& Ghafournia, 2016). This is followed by seven studies that employed qualitative research designs (see Alsheikh \& Mokhtari, 2011; Bastug \& Demirtas, 2016; Ciullo, et al., 2016; De Leon \& Tarrayo, 2014; Nurie, 2017; Omar \& Saufi, 2015; Wai et al., 2014) and seven studies that employed mixed-method research designs (see Semtin \& Maniam, 2015; Teba, 2017; Kasemsap \& Lee, 2015; Li, 2010; Lai, 2017; Solak \& Altay, 2014; Tercanlioglu, 2004).

The authors found that the most frequently occurred research approaches are the use of survey questionnaires followed by the use of interviews and observation respectively. There are 14 research which used the survey questionnaire research approach (see AD-Heisat, et al., 2009; Alsheikh \& Mokhtari, 2011; K. Chen \& S. Chen, 2015; De Leon \& Tarrayo, 2014; Kasemsap \& Lee, 2015; Lai, 2017; Melekoglu \& Wilkerson 2013; Semtin \& Maniam, 2015; Yukselir, 2014; Wai et al., 2014; Teba, 2017; Semtin \& Maniam, 2015; Migdadi \& Baniabdelrahman, 2016; Nasab \& Ghafournia, 2016). There are eight research which used the interview as the 
main tool to collect qualitative data (see Bastug \& Demirtas, 2016; Nurie, 2017; Omar \& Saufi, 2015; Semtin \& Maniam, 2015; Teba, 2017; Wai et al., 2014; Tercanlioglu, 2004; Semtin \& Maniam, 2015). As for the observation data collection technique, there are five research studies used this technique to collect data (see Bastug \& Demirtas, 2016; Ciullo et al., 2016; Omar \& Saufi, 2015; Teba, 2017; Ulu, 2017).

In terms of the number of participants in the research articles reviewed, the most focused population was on high school ESL/EFL students (see Chen \& Chen, 2015; Ciullo, et al., 2016; De Leon \& Tarrayo, 2014; Nasab \& Ghafournia 2016; Melekoglu \& Wilkerson 2013; Migdadi \& Baniabdelrahman,2016; Nurie, 2017; Semtin \& Maniam, 2015; Teba, 2017; Pinninti, 2016). There are six research conducted on elementary school ESL/EFL students (see Bastug \& Demirtas, 2016; Fu, et al., 2014; Lee \& Chang, 2017; Melekoglu \& Wilkerson 2013; ADHeisat et al., 2009; Ulu, 2017;) and only three studies focused on primary school ESL/EFL students (see Gomaa, 2015; Guo, 2013; and Omar \& Saufi, 2015). The least focused populations were on university students and language teachers (see Wai et al., 2014; Yukselir, 2014; Tercanlioglu, 2004; Solak \& Altay, 2014).

\section{Discussion and Conclusion}

All in all, from the review of the 27 carefully selected research articles, it can be concluded that the teachers are mostly aware of the importance of teaching reading strategies in the reading classroom. However, it was not clear what were the reasons for their choices to use these reading strategies with their ESL/EFL students. The authors believe that the choices made to use these strategies are really important to really enhance their effectiveness with the ESL/EFL students. The authors believe that teachers need to choose the best strategies that are suitable to the students' needs rather than using the same strategies throughout the term or the year. In other words, Yukselir (2014) suggested that "teachers should be aware of the reading strategies that their students use. Using some well established inventories of reading strategies, they should introduce their students to useful reading strategies which would increase their comprehension when reading English academic materials" (p. 72).

It is undeniable that Cognitive and Metacognitive Strategies are challenging to be used as ESL/EFL students still face different kinds of difficulties in their learning of reading comprehension (see Semtin \& Maniam, 2015; Kasemsap \& Lee, 2015; Alsheikh \& Mokhtari, 2011; Li, 2010; Küçükoğlu, 2012; Tercanlioglu, 2004; Pinninti, 2016; Gomaa, 2015; AD-Heisat et al., 2009; Guo, 2013; Yukselir, 2014; Teba, 2017; Solak \& Altay, 2014; and Lai, 2017). Moreover, AD-Heisat and colleagues (2009) indicated:

"the teachers tend to focus on the same reading strategies in class such as setting purpose of reading, working on understanding meaning of words and doing comprehension exercise. Other effective reading strategies such as setting context, relating the text to students' schemata and predicting or interpreting text are less frequently used" (p. 318).

However, such difficulties can be resolved if the teachers focus on teaching the students to overcome the reading challenges by choosing the best reading strategies that are catered to their ESL/EFL students' needs rather than using the most common reading strategies. Based on the reported findings, there is great importance in motivating, training and strengthening the students' level of reading comprehension through challenging them with different kinds of reading strategies. The ESL/EFL students might know the importance of each type of reading strategies. Therefore, to improve the ESL/EFL students' ability to apply different reading strategies, the teachers need to emphasize more on the challenging strategies which seem to be difficult for the students to understand.

This article highlights the importance of understanding the students' needs and reading difficulties before teaching the reading strategies in the classroom. Although the authors managed to highlight some of the effectiveness in teaching reading strategies, the findings cannot be generalized as it is important to continue testing the use of reading strategies to identify the most efficient reading methods to apply in the ESL/EFL language classroom. Therefore, the authors hope that more studies will focus on resolving the challenges of teaching reading strategies to assist the ESL/EFL students in the classroom. Furthermore, many other research methods, such as, discourse analysis, verbal protocol and action research are recommended to be conducted to provide in-depth findings regarding the effectiveness of using cognitive and metacognitive reading strategies to improve the students' reading comprehension.

\section{References}

AD- Heisat, M., Mohammed, S., Krishnasamy, K., \& Issa, J. (2009). The use of reading strategies in developing students' reading competency among primary school teachers. European Journal of Social Sciences, 12(2), 310-319.

Alsheikh, N., \& Mokhtari, K. (2010). An examination of the metacognitive reading strategies used by native speakers of Arabic when reading in English and Arabic. English Language Teaching, 4(2), 151-160. 
https://doi.org/10.5539/elt.v4n2p151

Bastug, M., \& Demirtas (2016). Child-centred reading intervention: See, talk, dictate, read, write. International Electronic Journal of Elementary Education, 8(4), 601-615.

Chen, K., \& Chen, S. (2015). The Use of EFL Reading strategies among high school students in Taiwan. An International Online Journal, 15(2), 156-166.

Ciullo, S., Lembke, E., Carlisle, A., Thomas, C., Goodwin, M., \& Judd, L. (2016). Implementation of evidence-based literacy practices in middle school response to intervention: An observation study. Learning Disability Quarterly, 39(1), 44-57. https://doi.org/10.1177/0731948714566120

De Leon, J., \& Tarrayo, V. (2014). "Cyber" reading in L2: Online reading strategies of students in a Philippine public high school. I-Manager's Journal on English Language Teaching, 4(2), 8-17. https://doi.org/10.26634/jelt.4.2.2793

Fu, Y., Chen, S., Wey, S., \& Chen, S. (2014). The effects of reading strategy instruction via electronic storybooks on EFL young readers' reading performance. International Journal of Contemporary Educational Research, 1(1), 9-20.

Gomaa, O. (2015). The effect of reciprocal teaching intervention strategy on reading comprehension skills of $5^{\text {th }}$ grade elementary school students with reading disabilities. International Journal of Psycho-Educational Sciences, 4(2), 39-45.

Guo, S. (2013). Using reading inventory as a learning tool. English Language Teaching, 6(1), 122-127. https://doi.org/10.5539/elt.v6n1p122

Kasemsap, B., \& Lee, H. (2015). L2 reading in Thailand: Vocational college students' application of reading strategies to their reading of English texts. An International Online Journal, 15(2), 101-117.

Kucukoglu, H. (2013). Improving reading skills through effective reading strategies. Procedia-Social and behavioral Sciences, 70, 709-714. https://doi.org/10.1016/j.sbspro.2013.01.113

Liaw, L. M. (2017). Reading strategy awareness training to empower online reading. The English Teacher, XXXVIII, 133-150.

Lee, C., \& Chang, C. (2017). Using the networked peer support strategy to enhance reading comprehension for students with various thinking styles. EURASIA Journal of Mathematics Science and Technology Education 13(5), 1501-1515.

Li, F. (2010). A study of English reading strategies used by senior middle school students. Asian Social Science, 6(10), 184-192.

Melekoğlu, M., \& Wilkerson, K. (2013). Motivation to read: How does it change for struggling readers with and without disabilities. International Journal of Instruction, 6(1), 77-88.

Migdadi, A., \& Baniabdelrahman, A. (2016). The effect of using team teaching on Jordanian EFL eleventh grade students' reading comprehension and their attitudes towards this strategy. Journal of Education and e-Learning Research, 3(2), 38-50. https://doi.org/10.20448/journal.509/2016.3.2/509.2.38.50

Nasab, E., \& Ghafournia, N. (2016). Relationship between multiple intelligence, reading proficiency, and implementing motivational strategies: A study of Iranian secondary students. International Journal of Education \& Literacy Studies, 4(3), 34-40. https://doi.org/10.7575/aiac.ijels.v.4n.3p.34

Nurie, Y. (2017). Pedagogical practices in teaching reading comprehension: A case Study of three EFL teachers in a secondary school in Ethiopia. PASAA. Journal of Language Teaching and Learning in Thailand, 54, 108-140.

Omar, A., \& Saufi, M. (2015). Storybook read-aloud to enhance students' comprehension skills in ESL classrooms: A case study. Dinamika Ilmu, 15(1), 99-113.

Pinninti, L. (2016). Metacognitive awareness of reading strategies: An Indian context. An International Online Journal, 16(1), 179-193.

Semtin, S., \& Maniam, M. (2015). Reading strategies among ESL Malaysian secondary school students. International Journal of Evaluation and Research in Education (IJERE), 4(2), 54-61.

Solak, E., \& Altay, F. (2014). The reading strategies used by prospective English teachers in Turkish ELT context. International Online Journal of Education and Teaching, 1(3), 78-89. 
Teba, S. (2017). Using effective strategies for error correction in EFL classes: A case study of secondary public schools in Benin. Journal of Education and e-Learning Research, 4(2), 63-71.

Tercanlioglu, L. (2004). Postgraduate students' use of reading strategies in L1 and ESL contexts: Links to success. International Education Journal, 5(4), 562-570.

Ulu, M. (2017). The effect of reading comprehension and problem solving strategies on classifying elementary $4^{\text {th }}$ grade students with high and low problem solving success. Journal of Education and Training Studies, 5(6), 44-63. https://doi.org/10.11114/jets.v5i6.2391

Wai, N., Chan, y., \& Zhang, K. (2014). Effective spelling strategies for students with dyslexia in Hong Kong secondary schools. International Journal of Special Education, 29(1), 1-11.

Yukselir, C. (2014). An investigation into the reading strategy use of EFL prep-class students. Procedia- Social and Behavioral Sciences, 158, 65-72. https://doi.org/10.1016/j.sbspro.2014.12.034

\section{Appendix A: Literature Review Matrix}

\begin{tabular}{|c|c|c|c|c|c|c|}
\hline \multirow[t]{2}{*}{ NO } & \multirow{2}{*}{$\begin{array}{l}\text { Authors } \\
\text { Title/ Year }\end{array}$} & \multicolumn{2}{|c|}{ Reading Strategies } & \multicolumn{3}{|c|}{ Research Methods } \\
\hline & & Cognitive & Metacognitive & Design & Method & Sample \\
\hline 1 & $\begin{array}{l}\text { Authors: } \\
\text { AD-Heisat, } \\
\text { Mohammed, } \\
\text { Krishnasamy, \& Issa } \\
\text { Title: The Use of } \\
\text { Reading Strategies } \\
\text { in Developing } \\
\text { Students Reading } \\
\text { Competency among } \\
\text { Primary School } \\
\text { Teachers } \\
\text { Year: } 2009\end{array}$ & 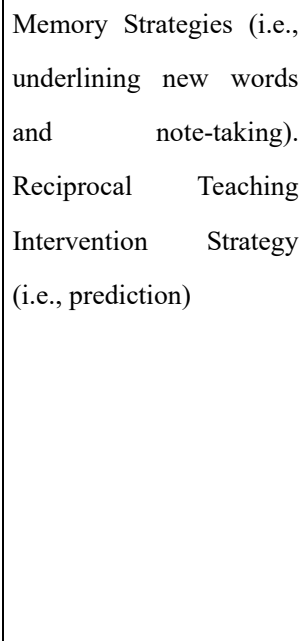 & $\begin{array}{l}\text { Support Strategy (i.e., } \\
\text { the use of dictionary) \& } \\
\text { Problem-Solving } \\
\text { Strategy (i.e., guessing } \\
\text { the meaning, reading } \\
\text { slowly) }\end{array}$ & Quantitative & $\begin{array}{l}\text { Survey } \\
\text { questionnaire }\end{array}$ & $\begin{array}{l}60 \text { primary school } \\
\text { teachers }) \text { in Penang } \\
\left(\begin{array}{lll}19 & \text { Males } \& & 41 \\
\text { Females }) & \end{array}\right.\end{array}$ \\
\hline 2 & $\begin{array}{l}\text { Authors: Alsheikh } \\
\text { \& Mokhtari } \\
\text { Title: An } \\
\text { Examination of the } \\
\text { Metacognitive } \\
\text { Reading Strategies } \\
\text { Used by Native } \\
\text { Speakers of Arabic } \\
\text { When Reading in } \\
\text { English and Arabic } \\
\text { Year: 2010 }\end{array}$ & $\begin{array}{l}\text { Memory Strategies (i.e., } \\
\text { visualising read } \\
\text { information, using prior } \\
\text { knowledge). Reciprocal } \\
\text { Teaching Intervention } \\
\text { Strategy (i.e., predicting, } \\
\text { reading slowly and } \\
\text { carefully, trying to stay } \\
\text { focused, pausing and } \\
\text { thinking about reading). } \\
\text { Monitoring Strategy } \\
\text { (re-reading the text, } \\
\text { asking oneself questions) }\end{array}$ & $\begin{array}{l}\text { Global strategies (i.e., } \\
\text { using prior knowledge, } \\
\text { determining what to } \\
\text { read closely, using } \\
\text { context clues, analysing } \\
\text { and evaluating the text, } \\
\text { checking understanding, } \\
\text { guessing the meaning of } \\
\text { the text \& predictions.) } \\
\text { Problem Solving } \\
\text { Strategies (i.e., reading } \\
\text { slowly and carefully, } \\
\text { trying to stay focused on } \\
\text { reading, adjusting } \\
\text { reading rate, paying } \\
\text { close attention to } \\
\text { reading, pausing and }\end{array}$ & Quantitative & $\begin{array}{l}\text { Survey } \\
\text { questionnaire }\end{array}$ & 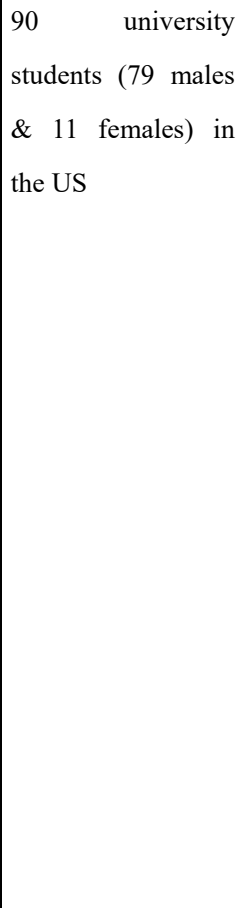 \\
\hline
\end{tabular}




\begin{tabular}{|c|c|c|c|c|c|}
\hline & & 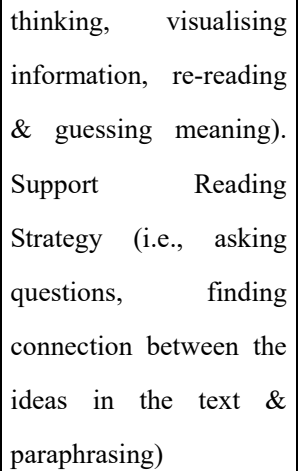 & & & \\
\hline 3 & $\begin{array}{l}\text { Authors: Bastug \& } \\
\text { Demirtas } \\
\text { Title: Child - } \\
\text { Centered Reading } \\
\text { Intervention: See, } \\
\text { Talk, Dictate, Read, } \\
\text { Write } \\
\text { Year: } 2016\end{array}$ & $\begin{array}{l}\text { Support Reading } \\
\text { Strategies (i.e., the use } \\
\text { of images \& note } \\
\text { taking) }\end{array}$ & Qualitative & $\begin{array}{lr}\text { Class } & \\
\text { Observation } \quad \& \\
\text { interview with } \\
\text { teacher }\end{array}$ & $\begin{array}{l}\text { One male student/ } \\
10 \text { years/ fourth } \\
\text { grade, and one } \\
\text { English teacher }\end{array}$ \\
\hline 4 & $\begin{array}{l}\text { Authors: Chen \& } \\
\text { Chen } \\
\text { Title: The Use of } \\
\text { EFL Reading } \\
\text { Strategies among } \\
\text { High School } \\
\text { Students in Taiwan } \\
\text { Year: 2015 }\end{array}$ & $\begin{array}{lrr}\text { Problem } & \text { Solving } \\
\text { Strategy } & \text { (i.e., } & \text { adjusting } \\
\text { the } & \text { reading } & \text { speed, } \\
\text { setting } & \text { purpose } & \text { for } \\
\text { reading, } & \text { directed } \\
\text { attention, } & \text { questioning, } \\
\text { prediction, } & \text { guessing the } \\
\text { meaning } & \& & \text { rereading } \\
\text { the } & \text { text). } & \text { Global } \\
\text { Reading } & \text { Strategies (i.e., } \\
\text { determining } & \text { what } & \text { to } \\
\text { read, } & \text { using } & \text { context } \\
\text { clues, } & \text { using } \\
\text { typographical } & \text { features, } \\
\text { analysing and evaluating } \\
\text { the } & \text { text, } & \text { checking } \\
\text { understanding } & \quad \& \\
\text { guessing the } & \text { meaning of } \\
\text { the } & \text { text). } & \text { Support } \\
\text { Reading } & \text { Strategies (i.e., } \\
\text { note-taking, } & \text { underlining } \\
\text { or } & \text { circling } & \text { particular } \\
\text { sentences, } & \text { reference } \\
\text { materials } & \text { 'dictionary', } \\
\text { asking } & \text { self-questions } \& \\
\text { paraphrasing) } & \end{array}$ & Quantitative & $\begin{array}{l}\text { Survey } \\
\text { questionnaire }\end{array}$ & $\begin{array}{l}\text { 1,259 high school } \\
\text { students (533 Males } \\
\& 726 \text { females) }\end{array}$ \\
\hline
\end{tabular}




\begin{tabular}{|c|c|c|c|c|c|c|}
\hline 5 & $\begin{array}{l}\text { Authors: Ciullo, } \\
\text { Lemke, Carlisle, } \\
\text { Thomas, Goodwin, } \\
\text { \& Judd } \\
\text { Title: } \\
\text { Implementation of } \\
\text { Evidence-Based } \\
\text { Literacy Practices in } \\
\text { Middle School } \\
\text { Response to } \\
\text { Intervention: An } \\
\text { Observation Study } \\
\text { Year: } 2016\end{array}$ & & $\begin{array}{l}\text { Problem } \\
\text { Strategies } \\
\text { prediction, } \\
\text { summarisation, silent } \\
\text { reading, guessing the } \\
\text { meaning of the difficult } \\
\text { words). Support } \\
\text { Reading Strategies (i.e., } \\
\text { reference materials, } \\
\text { finding connection } \\
\text { between the ideas in the } \\
\text { text, the use of gadget } \\
\text { and tools) }\end{array}$ & Qualitative & Observation & $\begin{array}{l}3 \text { middle schools } \\
(7,700 \\
\text { students-Grade } 3 \text { to } \\
\text { 12) \& } 8 \text { teachers }\end{array}$ \\
\hline 6 & $\begin{array}{l}\text { Authors: De Leon } \\
\text { \& Tarrayo } \\
\text { Title: "Cyber" } \\
\text { Reading in } \text { L2: } \\
\text { Online Reading } \\
\text { Strategies } \\
\text { Students in a } \\
\text { Philippine } \\
\text { High School } \\
\text { Year: } 2014\end{array}$ & & 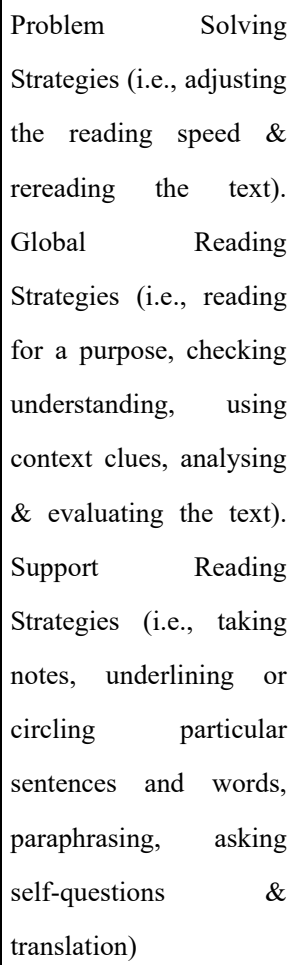 & Quantitative & $\begin{array}{l}\text { Descriptive } \\
\text { approach/ } \\
\text { Survey }\end{array}$ & $\begin{array}{l}100 \text { students from a } \\
\text { Public School in } \\
\text { Quezon City (14-17 } \\
\text { years old). }\end{array}$ \\
\hline 7 & $\begin{array}{l}\text { Authors: Fu, Chen, } \\
\text { Wei, \& Chen } \\
\text { Title: The Effects of } \\
\text { Reading Strategy } \\
\text { Instruction via } \\
\text { Electronic } \\
\text { Storybooks on EFL } \\
\text { Young Readers' } \\
\text { Reading } \\
\text { Performance } \\
\text { Year: } 2014\end{array}$ & $\begin{array}{l}\text { Reciprocal Teaching } \\
\text { Intervention Strategies } \\
\text { (i.e., predicting, inferring } \\
\& \text { identifying the main } \\
\text { ideas) }\end{array}$ & & Quantitative & \begin{tabular}{|l|} 
Quasi \\
-experimental \\
research and \\
survey \\
questionnaires
\end{tabular} & 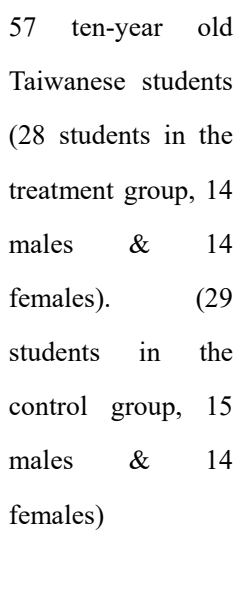 \\
\hline 8 & Author: Gomaa & Monitoring & & Quantitative & Survey & Elementary \\
\hline
\end{tabular}




\begin{tabular}{|c|c|c|c|c|c|c|}
\hline & $\begin{array}{l}\text { Title: The Effect of } \\
\text { Reciprocal Teaching } \\
\text { Intervention } \\
\text { Strategy on Reading } \\
\text { Comprehension } \\
\text { Skills of 5Th Grade } \\
\text { Elementary School } \\
\text { Students with } \\
\text { Reading Disabilities } \\
\text { Year: } 2015\end{array}$ & $\begin{array}{l}\text { (i.e., paying attention \& } \\
\text { assessing } \\
\text { self-understanding). } \\
\text { Reciprocal Teaching } \\
\text { Intervention Strategies } \\
\text { (i.e., questioning, } \\
\text { summarising, predicting } \\
\text { \& clarifying) }\end{array}$ & & & questionnaire & $\begin{array}{l}\text { school students ( } 33 \\
\text { students in the } \\
\text { treatment group \& } \\
33 \text { students in the } \\
\text { control group) }\end{array}$ \\
\hline 9 & $\begin{array}{l}\text { Author: Guo } \\
\text { Title: Using } \\
\text { Reading Inventory } \\
\text { as a Learning Tool } \\
\text { Year: } 2013\end{array}$ & $\begin{array}{l}\text { Retrieval Strategies (i.e., } \\
\text { high use on context clues } \\
\text { to find the meanings). } \\
\text { Planning strategies (i.e., } \\
\text { less use on staying } \\
\text { focused on reading). } \\
\text { Memory Strategy (i.e., } \\
\text { less use on visualising } \\
\text { read information \& slow } \\
\text { reading), Monitoring } \\
\text { Strategies (i.e., less use } \\
\text { on directing attention, } \\
\text { assessing } \\
\text { self-understanding \& } \\
\text { rereading the text) }\end{array}$ & & Qualitative & $\begin{array}{l}\text { Interview and } \\
\text { observation }\end{array}$ & $\begin{array}{l}1 \text { student } / 8 \text { years } \\
\text { old }\end{array}$ \\
\hline 10 & $\begin{array}{l}\text { Authors: Kasemsap } \\
\text { \& Lee } \\
\text { Title: L2 Reading in } \\
\text { Thailand: Vocational } \\
\text { College Students' } \\
\text { Application of } \\
\text { Reading Strategies } \\
\text { to Their Reading of } \\
\text { English Texts } \\
\text { Year: } 2015\end{array}$ & $\begin{array}{lrr}\text { Comprehending } & \\
\text { Strategies } & \text { (i.e., } \\
\text { dictionary, } & \text { visualising } \\
\text { read information } & \& \\
\text { translation) } & \text { Memory } \\
\text { Strategies } & \text { (i.e., } \\
\text { underlining } & \text { and } \\
\text { highlighting } & \\
\text { information). } & \text { Retrieval } \\
\text { Strategies } & & \text { (i.e., } \\
\text { previewing } & \text { the } & \text { text } \\
\text { before } & \text { reading, } & \text { using } \\
\text { prior knowledge } & \text { \& } & \text { using } \\
\text { context } & & \text { clues). } \\
\text { Monitoring } & \text { Strategies } \\
\text { (i.e., } & \text { asking } & \text { themselves } \\
\text { questions) } & & \end{array}$ & $\begin{array}{l}\text { Problem } r \text { solving } \\
\text { Strategy } \text { (i.e., checking } \\
\text { understanding, directed } \\
\text { attention \& rereading } \\
\text { the text). Global } \\
\text { Reading Strategy (i.e., } \\
\text { purpose in mind when } \\
\text { reading) }\end{array}$ & $\begin{array}{l}\text { Mixed-method } \\
\text { research }\end{array}$ & $\begin{array}{l}\text { Questionnaires } \\
\text { survey \& } \\
\text { semi-structured } \\
\text { interview }\end{array}$ & $\begin{array}{lll}24 \quad \text { students } & (12 \\
\text { females \& } & 12 \\
\text { males }) & & \end{array}$ \\
\hline 11 & Author: Kucukoglu. & Monitoring & & Qualitative & Quasi & 14 students \\
\hline
\end{tabular}




\begin{tabular}{|c|c|c|c|c|c|c|}
\hline & $\begin{array}{lr}\text { Title: } & \text { Improving } \\
\text { Reading } & \text { Skills } \\
\text { through } & \text { Effective } \\
\text { Reading } & \text { Strategies } \\
\text { Year: } 2013 & \end{array}$ & \begin{tabular}{|lr} 
(i.e., setting a purpose for \\
reading). & Memory \\
Strategies & (i.e., \\
visualising & read \\
information). & Retrieval \\
Strategies & (i.e., \\
prior & using \\
Reciprocal & Teaching \\
Intervention & Strategies \\
(i.e., & summarizing, \\
predicting & $\&$ \\
questioning) &
\end{tabular} & & action research & experimental & \\
\hline 12 & \begin{tabular}{|lr}
\multicolumn{2}{|l}{ Author: Lai } \\
Title: & Reading \\
Strategy & Awareness \\
Training & to \\
Empower & Online \\
Reading & \\
Year: 2017 &
\end{tabular} & 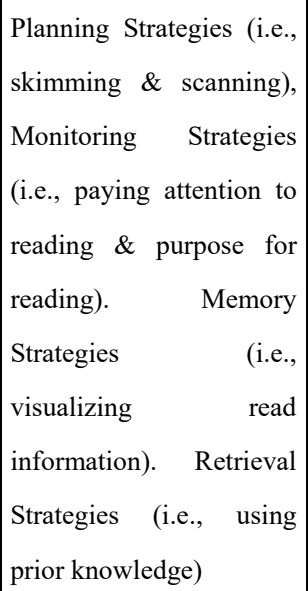 & 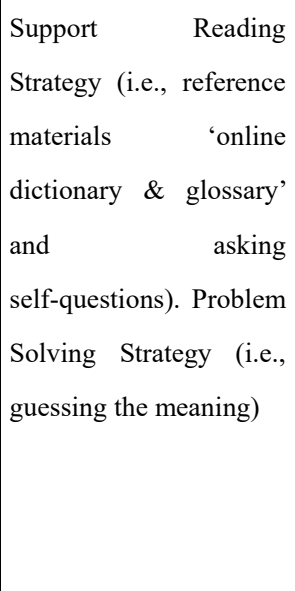 & Mixed-method & $\begin{array}{l}\text { Survey } \\
\text { questionnaires, } \\
\text { interviews, }\end{array}$ & $\begin{array}{l}8 \text { secondary school } \\
\text { students }\end{array}$ \\
\hline 13 & $\begin{array}{llr}\text { Authors: } & \text { Lee } & \& \\
\text { Chang } & & \\
\text { Title: } & \text { Using } & \text { the } \\
\text { Networked } & \text { Peer } \\
\text { Support } & \text { Strategy } & \text { to } \\
\text { Enhance } & \text { Reading } \\
\text { Comprehension } & \text { for } \\
\text { Students } & \text { with } \\
\text { Various } & \text { Thinking } \\
\text { Styles } & \\
\text { Year: } 2017\end{array}$ & & $\begin{array}{l}\text { Support Reading } \\
\text { Strategies (i.e., the use } \\
\text { of technology gadget, } \\
\text { extra reading techniques } \\
\& \text { asking self-questions } \\
\text { to find the answers) }\end{array}$ & Quantitative & Experimental & $\begin{array}{l}53 \text { elementary } \\
\text { students } \\
\text { students } \\
\text { participated in the } \\
\text { networked peer } \\
\text { support activities \& } \\
26 \quad \text { students } \\
\text { participated in the } \\
\text { networked peer } \\
\text { assessment } \\
\text { activities in the } \\
\text { control group). }\end{array}$ \\
\hline 14 & 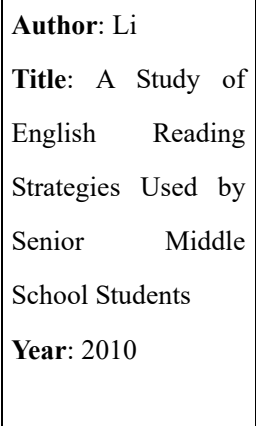 & & $\begin{array}{l}\text { Problem Solving } \\
\text { Strategies (i.e., adjusting } \\
\text { the reading speed \& } \\
\text { rereading the text). } \\
\text { Support reading } \\
\text { Strategies (i.e., reading } \\
\text { aloud when the text gets } \\
\text { difficult, r asking }\end{array}$ & Quantitative & $\begin{array}{l}\text { Survey } \\
\text { questionnaire }\end{array}$ & $\begin{array}{l}180 \text { middle school } \\
\text { students ( } 137 \text { males } \\
\& 43 \text { females) }\end{array}$ \\
\hline
\end{tabular}




\begin{tabular}{|c|c|c|c|c|c|}
\hline & & $\begin{array}{l}\text { self-questions \& the use } \\
\text { of discussion). Global } \\
\text { Reading Strategies (i.e., } \\
\text { getting more } \\
\text { information on the } \\
\text { topic) }\end{array}$ & & & \\
\hline 15 & $\begin{array}{l}\text { Authors: Melekoğlu } \\
\text { \& Wilkerson } \\
\text { Title: Motivation to } \\
\text { Read: How Does It } \\
\text { Change for } \\
\text { Struggling Readers } \\
\text { with and without } \\
\text { Disabilities } \\
\text { Year: } 2013\end{array}$ & 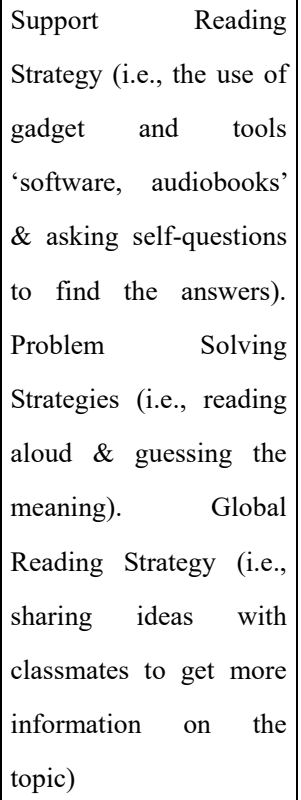 & Quantitative & $\begin{array}{l}\text { Survey } \\
\text { questionnaire }\end{array}$ & $\begin{array}{l}45 \text { elementary \& } \\
\text { high }\end{array}$ \\
\hline 16 & $\begin{array}{lr}\text { Authors: } & \text { Migdadi } \\
\text { \& Baniabdelrahman } \\
\text { Title: } & \text { The } \\
\text { Using } & \text { Team } \\
\text { Teaching } & \text { on } \\
\text { Jordanian } & \text { EFL } \\
\text { Eleventh } & \text { Grade } \\
\text { Students' } & \text { Reading } \\
\text { Comprehension } & \text { and } \\
\text { Their } & \text { Attitudes } \\
\text { Towards } & \text { This } \\
\text { Strategy } & \\
\text { Year: } 2016 & \end{array}$ & $\begin{array}{l}\text { Problem solving \& } \\
\text { Support Strategy (i.e., } \\
\text { team teachers). Global } \\
\text { Reading Strategies (i.e., } \\
\text { sharing ideas \& getting } \\
\text { more information on } \\
\text { specific topics }\end{array}$ & Quantitative & \begin{tabular}{|l|} 
Quasi \\
experimental \& \\
Survey \\
Questionnaires
\end{tabular} & $\begin{array}{l}48 \text { high school } \\
\text { students } \quad(23 \\
\text { treatment group \& } \\
25 \text { control group) }\end{array}$ \\
\hline 17 & $\begin{array}{l}\text { Authors: Nasab \& } \\
\text { Ghafournia } \\
\text { Title: Relationship } \\
\text { between Multiple } \\
\text { Intelligence, } \\
\text { Reading Proficiency, } \\
\text { and Implementing } \\
\text { Motivational } \\
\text { Strategies: A Study }\end{array}$ & $\begin{array}{l}\text { Support Reading } \\
\text { (i.e., motivational } \\
\text { strategies) }\end{array}$ & $\begin{array}{l}\text { Quantitative } \\
\text { (correlational) }\end{array}$ & $\begin{array}{l}\text { Survey } \\
\text { questionnaires }\end{array}$ & 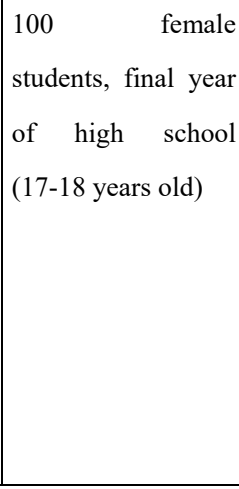 \\
\hline
\end{tabular}




\begin{tabular}{|c|c|c|c|c|c|c|}
\hline & $\begin{array}{l}\text { of Iranian Secondary } \\
\text { Students } \\
\text { Year: } 2016\end{array}$ & & & & & \\
\hline 18 & $\begin{array}{l}\text { Author: Nurie } \\
\text { Title: Pedagogical } \\
\text { Practices in } \\
\text { Teaching Reading } \\
\text { Comprehension: A } \\
\text { Case Study of Three } \\
\text { EFL Teachers in a } \\
\text { Secondary School in } \\
\text { Ethiopia } \\
\text { Year: } 2017\end{array}$ & 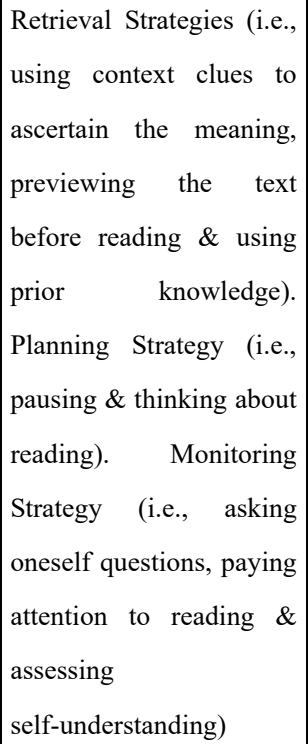 & $\begin{array}{l}\text { Support Reading (i.e., } \\
\text { paraphrasing \& asking } \\
\text { self-questions to find the } \\
\text { answers). Global } \\
\text { Reading Strategies (i.e., } \\
\text { sharing and getting } \\
\text { more information \& } \\
\text { guiding the students to } \\
\text { have a reading purpose). } \\
\text { Problem } \\
\text { strategy (i.e., guessing } \\
\text { the meaning) }\end{array}$ & Qualitative & Interview & $\begin{array}{l}3 \text { male teachers } \\
\text { (more than } 20 \text { years } \\
\text { of teaching } \\
\text { experience) }\end{array}$ \\
\hline 19 & $\begin{array}{l}\text { Authors: Omar \& } \\
\text { Saufi } \\
\text { Title: Storybook } \\
\text { Read-Aloud to } \\
\text { Enhance Students' } \\
\text { Comprehension } \\
\text { Skills in ESL } \\
\text { Classrooms: A Case } \\
\text { Study } \\
\text { Year: } 2015\end{array}$ & & $\begin{array}{l}\text { Problem } r \text { Solving } \\
\text { Strategy (i.e., reading } \\
\text { aloud, rereading the text } \\
\text { \& guessing the meaning } \\
\text { of difficult words). } \\
\text { Support Strategy (i.e., } \\
\text { using reference } \\
\text { materials 'translation' \& } \\
\text { asking self-questions to } \\
\text { find the answers). } \\
\text { Global Reading Strategy } \\
\text { (i.e., interacting, sharing } \\
\text { \& getting more } \\
\text { information) }\end{array}$ & Qualitative & $\begin{array}{l}\text { Observation \& } \\
\text { interview }\end{array}$ & $\begin{array}{l}3 \text { primary school } \\
\text { English language } \\
\text { teachers }\end{array}$ \\
\hline 20 & $\begin{array}{l}\text { Author: Pinninti } \\
\text { Title: Metacognitive } \\
\text { Awareness of } \\
\text { Reading Strategies: } \\
\text { An Indian Context } \\
\text { Year: } 2016\end{array}$ & $\begin{array}{lrr}\text { Monitoring Strategy (i.e., } \\
\text { predicting, setting } & \text { a } \\
\text { purpose for reading) } & \\
\text { Memory } & \text { Strategy } & \text { (i.e., } \\
\text { underlining } & \text { and } \\
\text { highlighting } & \text { information, } \\
\text { recalling the } & \text { summary } \& \\
\text { visualizing } & \text { read } \\
\text { information). } & \\
\text { Comprehending } & \text { Strategy } \\
\text { (i.e., } & \text { dictionary } & \& \\
\text { translating). } & \text { Planning }\end{array}$ & 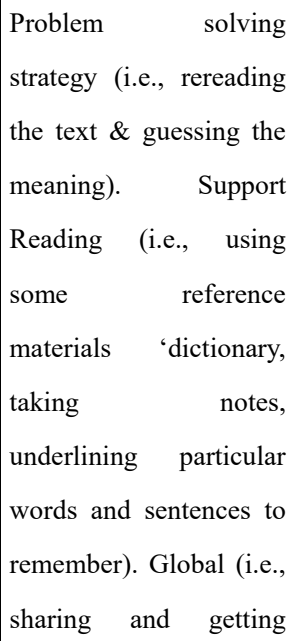 & Qualitative & $\begin{array}{l}\text { Interview and } \\
\text { observation }\end{array}$ & $\begin{array}{ll}9 \quad \text { (ninth } & \text { grade } \\
\text { students/ } & 13-14 \\
\text { years old) } & \end{array}$ \\
\hline
\end{tabular}




\begin{tabular}{|c|c|c|c|c|c|c|}
\hline & & $\begin{array}{l}\text { Strategy (i.e., reading } \\
\text { slowly and carefully). } \\
\text { Retrieval Strategies (i.e., } \\
\text { previewing text before } \\
\text { reading) }\end{array}$ & more information) & & & \\
\hline 21 & $\begin{array}{lr}\text { Authors: } & \text { Semtin \& } \\
\text { Maniam } & \\
\text { Title: } & \text { Reading } \\
\text { Strategies } & \text { among } \\
\text { ESL } & \text { Malaysian } \\
\text { Secondary } & \text { School } \\
\text { Students } & \\
\text { Year: } 2015 & \end{array}$ & 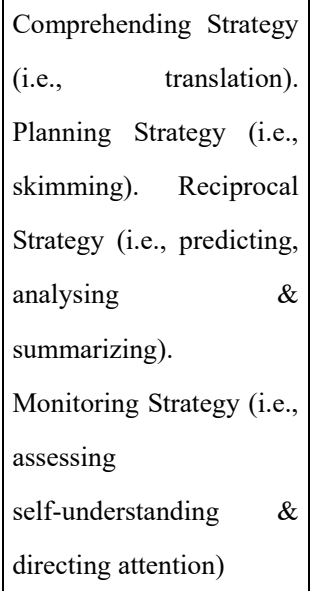 & 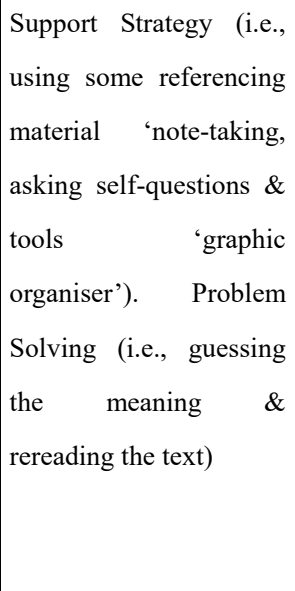 & Mixed method & $\begin{array}{l}\text { Survey } \\
\text { questionnaire \& } \\
\text { interviews }\end{array}$ & $\begin{array}{l}94 \text { high school } \\
\text { students }\end{array}$ \\
\hline 22 & $\begin{array}{l}\text { Authors: Solak \& } \\
\text { Altay } \\
\text { Title: The Reading } \\
\text { Strategies Used by } \\
\text { Prospective English } \\
\text { Teachers in Turkish } \\
\text { ELT Context } \\
\text { Year: } 2014\end{array}$ & $\begin{array}{l}\text { Planning } \text { Strategy (i.e., } \\
\text { skimming, trying to stay } \\
\text { focused on reading, } \\
\text { reading } \\
\text { Monitoring Strategy (i.e., } \\
\text { assessing } \\
\text { self-understanding, } \\
\text { paying attention to } \\
\text { reading, setting a purpose } \\
\text { for reading). Retrieval } \\
\text { Reading (i.e., previewing } \\
\text { the text before reading, } \\
\text { using context clues, } \\
\text { analysing). Memory } \\
\text { Strategy (i.e., visualizing } \\
\text { read information) }\end{array}$ & $\begin{array}{l}\text { Support Reading (i.e., } \\
\text { circling and underlining } \\
\text { particular, using some } \\
\text { reference materials } \\
\text { 'taking notes', using } \\
\text { tools 'graphics, pictures, } \\
\text { figures', asking } \\
\text { self-questions to find the } \\
\text { answers, underlining } \\
\text { sentences or words \& } \\
\text { paraphrasing). Problem } \\
\text { Solving (i.e., rereading } \\
\text { the text, reading aloud, } \\
\text { adjusting the reading } \\
\text { speed \& guessing the } \\
\text { meaning). } \\
\text { Reading (i.e., sharing } \\
\text { and getting more } \\
\text { information \& guiding } \\
\text { the students to have a } \\
\text { purpose in mind when } \\
\text { reading) }\end{array}$ & Quantitative & $\begin{array}{l}\text { Survey } \\
\text { questionnaires }\end{array}$ & $\begin{array}{l}130 \text { teachers }(100 \\
\text { females \& } 30 \\
\text { males) }\end{array}$ \\
\hline 23 & 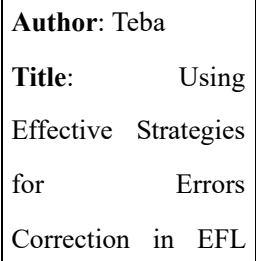 & $\begin{array}{l}\text { Comprehending Strategy } \\
\text { (i.e., translation) }\end{array}$ & 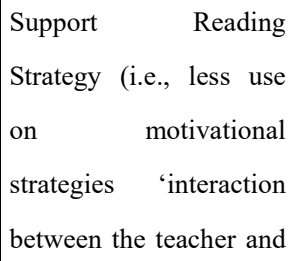 & Mixed method & $\begin{array}{l}\text { Survey } \\
\text { questionnaire, } \\
\text { observation \& } \\
\text { interview }\end{array}$ & $\begin{array}{l}80 \text { teachers \& } 534 \\
\text { high school } \\
\text { students }\end{array}$ \\
\hline
\end{tabular}




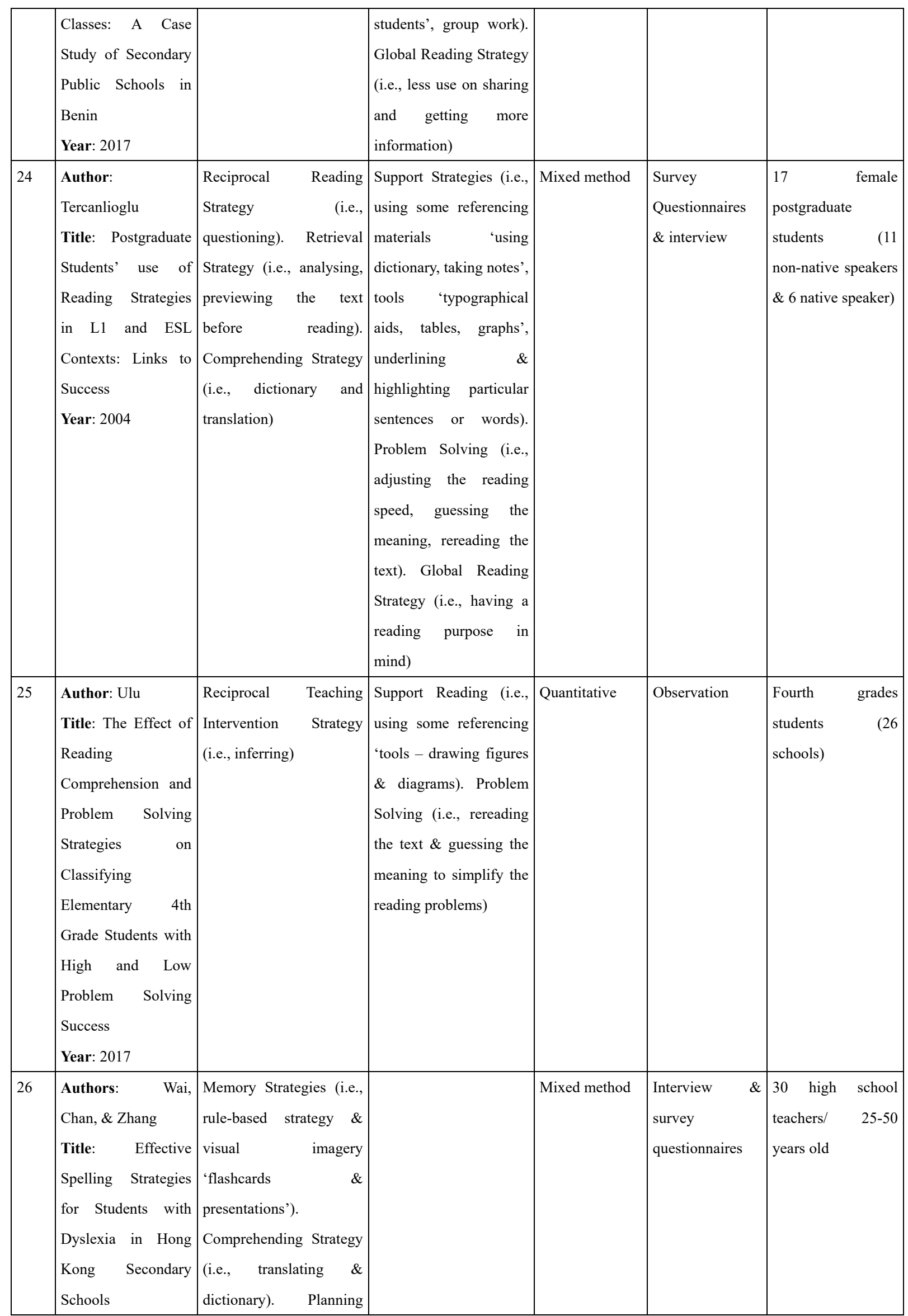




\begin{tabular}{|c|c|c|c|c|c|c|}
\hline & Year: 2014 & $\begin{array}{l}\text { Strategy (i.e., pausing } \\
\text { and thinking about } \\
\text { reading, trying to stay } \\
\text { focused on reading, } \\
\text { reading slowly and } \\
\text { carefully \& determine } \\
\text { what to read) }\end{array}$ & & & & \\
\hline 27 & $\begin{array}{l}\text { Author: Yukselir } \\
\text { Title: An } \\
\text { Investigation into } \\
\text { the Reading Strategy } \\
\text { Use of EFL } \\
\text { Prep-Class Students } \\
\text { Year: } 2014\end{array}$ & $\begin{array}{l}\text { Reciprocal Teaching } \\
\text { Intervention Strategy } \\
\text { (i.e., predicting \& } \\
\text { clarifying) } \\
\text { Planning Strategy (i.e., } \\
\text { skimming, pausing \& } \\
\text { thinking about reading). } \\
\text { Monitoring Strategy (i.e., } \\
\text { paying attention to } \\
\text { reading). } \\
\text { Comprehending (i.e., } \\
\text { Strategies } \\
\text { translation). } \\
\text { Retrieval Strategies (i.e., } \\
\text { using context clue to } \\
\text { ascertain the meaning) } \\
\text { Memory Strategy (i.e., } \\
\text { visualising read } \\
\text { information) }\end{array}$ & $\begin{array}{l}\text { Problem Solving } \\
\text { Strategy (i.e., adjusting } \\
\text { the reading speed). } \\
\text { Support Strategy (i.e., } \\
\text { underlining or } \\
\text { highlighting particular } \\
\text { sentences or words) }\end{array}$ & Quantitative & $\begin{array}{l}\text { Survey } \\
\text { questionnaire }\end{array}$ & 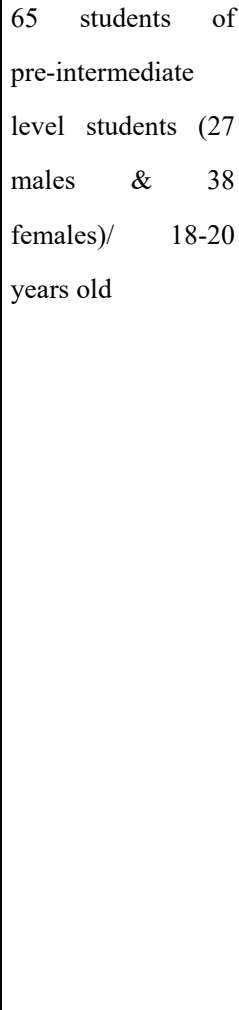 \\
\hline
\end{tabular}

\section{Copyrights}

Copyright for this article is retained by the author(s), with first publication rights granted to the journal.

This is an open-access article distributed under the terms and conditions of the Creative Commons Attribution license (http://creativecommons.org/licenses/by/4.0/). 